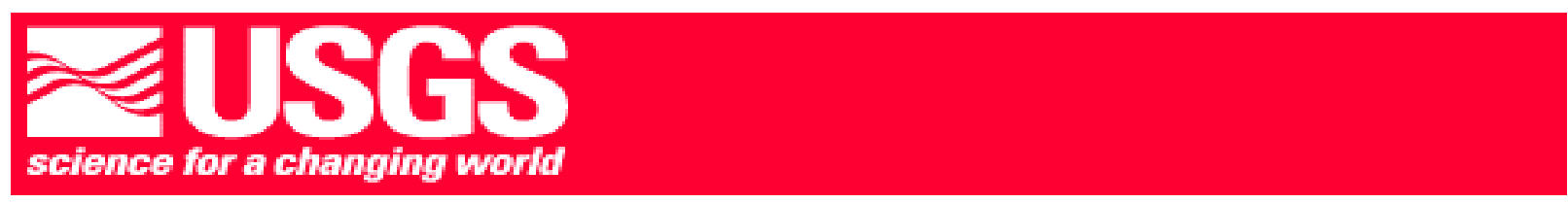

\title{
Characteristics of Water-Well Yields in the Blue Ridge of Loudoun County, Virginia
}

by David M. Sutphin ${ }^{1}$, Lawrence J. Drew ${ }^{1}$, John H. Schuenemeyer ${ }^{2}$, and William C. Burton ${ }^{3}$

Open-File Report 00-280

2000

This report is preliminary and has not been reviewed for conformity with U.S. Geological Survey editorial standards (or with the North American Stratigraphic Code). Any use of trade, product, or firm names is for descriptive purposes only and does not imply endorsement by the U.S. Government.

U.S. DEPARTMENT OF THE INTERIOR

U.S. GEOLOGICAL SURVEY

${ }^{1}$ U.S. Geological Survey, 954 National Center, Reston, VA 20192

${ }^{2}$ U.S. Geological Survey, c/ o Department of Geography, University of Delaware, Newark, DE 19716

${ }^{3}$ U.S. Geological Survey, 926 National Center, Reston, VA 20192 


\section{Contents}

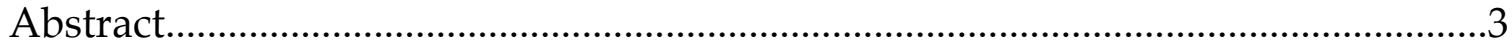

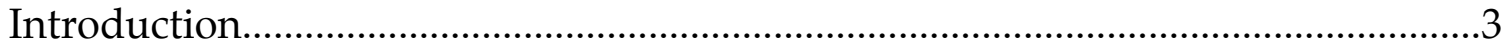

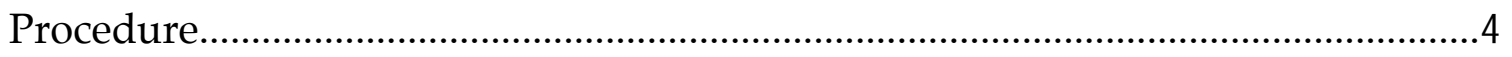

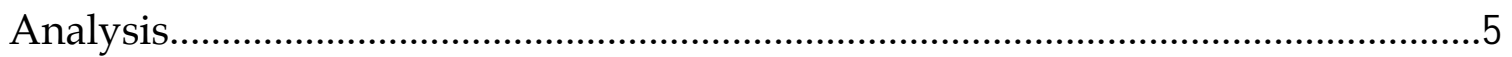

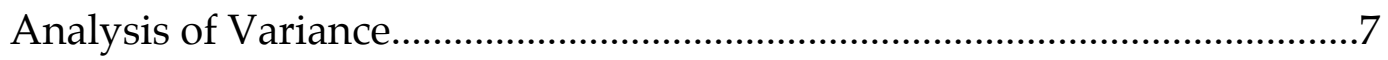

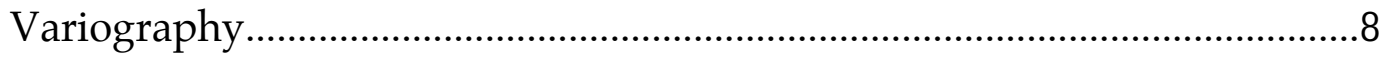

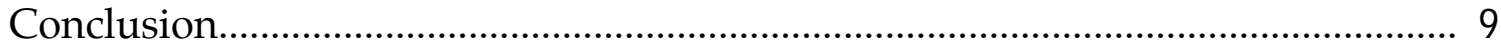

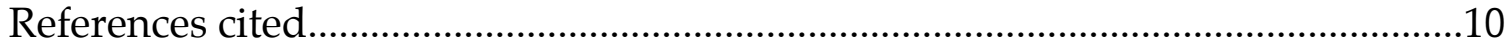

Tables

Table 1. Rock types and their water wells in the Blue Ridge Province of Loudoun County, Virginia, sorted by geologic age and alphabetically.....11

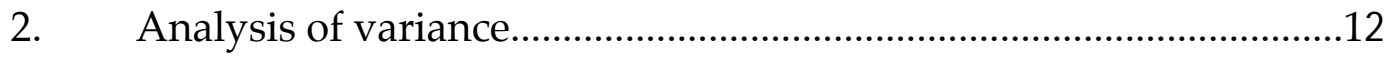

3. Bonferroni adjustment for significance level between pairs of yields with rock types...........................................................................................13

\section{Figures}

Figure 1. Locations of water wells in the Blue Ridge of Loudoun County, Virginia......

2. Graph showing mean yields of wells in rock types in the Blue Ridge of Loudoun County, Virginia, having 30 or more nonzero-yield wells.....15 3. Variogram surface for 1,232 low-yield wells of the Marshall metagranite ( $\mathrm{mmb}, \mathrm{Ymc}$, and $\mathrm{Yml}$ ) in the Blue Ridge of Loudoun County, Virginia 


\begin{abstract}
Mean yields and the numbers of wells drilled are presented for 35 rock types containing 4,115 wells in the Blue Ridge of Loudoun County, Virginia. Analysis of variance of the well yields shows that Harper's Formation phyllite and Catoctin Formation metabasalt have yields significantly different from those of other rock types. Preliminary variography has identified an anisotropy that roughly parallels the general compressional trend of the Blue Ridge.
\end{abstract}

\title{
Introduction
}

Loudoun County, Virginia, is underlain by rocks of the Blue Ridge and Piedmont Provinces and the Early Mesozoic Culpeper basin and consequently has a diversity of rock types (Southworth and others, 1999). The rocks of the Blue Ridge extend from the western border of the county to the east side of Catoctin Mountain and along the length of the western half of the county from north to south. These rocks have been divided into numerous geologic units (rock types) that have been repeatedly penetrated by wells in the search for water for houses and communities. In doing so, a great deal of well data have been generated.

In March, 2000, we were given by the State of Virginia the data set containing information on the water wells in Loudoun County, Virginia, and asked to determine whether rock type was a significant factor in the variability seen in yields of the wells. Our research showed that the mean yields of wells in some few rock types were significantly different than the mean yields of wells in other rock types. We used data from 3,901 wells that had yields greater than zero, because we could not distinguish the zero-yield wells from those where no yield data was provided. The mean yields calculated for the rock types were higher than the true mean yields, because we had necessarily left out the zero-yield wells.

The purpose of this study is to use the water-well data to determine if the rock types and geologic structures present in the Blue Ridge have any bearing on the yields of the wells drilled into them, and to present preliminary variography to determine if additional spatial analysis is warranted. 
The drilling of water wells is a complex socio-economic process having numerous variables. Factors such as initial well yield, depth, elevation, and rock type tell only part of the story. Other pertinent factors include the drilling technology employed, the thickness of overburden or regolith reported as depth to bedrock, and the topographic location of the well site.

Over the last decade or so, drilling technology has changed with the introduction of rotary drilling and hydrofracking. Rotary drills are faster and can drill deeper than the cable tools that had been used previously.

Hydrofracturing or hydrofracking is the process of pumping high-pressure water into a bedrock formation via the well to increase the size and extent of existing bedrock fractures, thereby enlarging the network of water-bearing fractures and increasing the area supplying water to the well (NHDES, 2000, http:/ / www.des.state.nh.us/ws-1-3.htm).

Daniel (1989) showed that wells drilled in draws and valleys have average yields three times those of wells drilled on hills and ridges. He found that wells in the most productive rock types have average yields twice those of wells in the least productive types. Wells sited in draws and valleys in the most productive rock types average five times more yield than wells on hills and ridges in the least productive types. Daniel (1989) demonstrated also that well diameter can have a significant influence on yield and for a given depth, yield is directly proportional to well diameter.

Along with this variability on yield imposed by topography, rock type may exert an influence on whether a well provides the amount of yield sought. With modern drilling technology, the required yield is usually attained; however, a favorable rock type may make the expenditure of additional funds to employ that technology unnecessary.

\section{Procedure}

The data set for the water wells of Loudoun County, Virginia, was provided by the Virginia state geologist. Of the 23,245 wells in the data set, 16,756 originate in rock units found in the Blue Ridge. Unfortunately, for 12,827 of these wells, the reported yield is zero. A number of zero-yield wells are to be expected in almost any area. Experience in the Pinardville, NH, quadrangle 
(Drew and others, 2000), for example, has shown that zero-yield wells may make up about 10 per cent of the data. A closer look at the zero-yield well data reveals that most of them have no reported secondary or tertiary yields, and other data elements, such as elevation and casing depth, are missing. Because it was felt that the vast majority of the zero-yield wells were in fact wells with no reported yield data rather than dry holes, the zero-yield wells were removed from the data set. This was done to remove the ambiguity of not knowing whether a zero yield meant that there was no water in the well or whether no yield data had been reported. However, 214 wells of the zero-yield wells have a prefix of "WWDH" in the site-id field designating them as dry holes, so these wells were included in the analysis.

After eliminating the several wells that had been hydrofracked, and one additional well because its reported depth had been entered erroneously, this analysis is based on data for 4,115 wells in the Blue Ridge of Loudoun County, Virginia, with the 214 zero-yield wells making up about 5.2 per cent of the wells.

Using Geographical Information System (GIS) software, each well in the data set was matched with its corresponding uppermost bedrock unit on the geologic map of Loudoun County (Southworth and others, 1999), attributes of the rock unit were added to the data set, and areas of the rock units in the Blue Ridge were calculated. Many of the rock attributes and much of the well data were unnecessary for this study and were selectively removed. The resultant data set contained the following 11 fields from the original data set: site id, month, day, and year of completion, base elevation, total yield, bedrock depth, total depth, rock unit, UTM easting, and UTM northing.

\section{Analysis}

Thirty-five different rock units in the Blue Ridge of Loudoun County contain at least one water well. These rocks range in age from the Middle Proterozoic to the Jurassic and from metasediments such as marble, metagreywacke, and metaarkose to igneous rocks such as diabase and granite, plus other metamorphic rocks such as metagranite and phyllite. Descriptions of these units are found in Southworth and others (1999) and are summarized in table 1. 
Middle Proterozoic rocks in the Blue Ridge of Loudoun County have a total area of about $487.8 \mathrm{~km}^{2}$, with the three units of Marshall metagranite, (Ymb, Ymc, and Yml) making up $194.3 \mathrm{~km}^{2}$ of that. Late Proterozoic rocks account for 282.9 $\mathrm{km}^{2}$ with the five units of Catoctin Formation (Zc, Zcm, Zcp, Zcr, and Zcs) accounting for $201.9 \mathrm{~km}^{2}$ of that area. Cambrian rocks make up $51.8 \mathrm{~km}^{2}$, and Jurassic age rocks make up $3.0 \mathrm{~km}^{2}$ of the Blue Ridge of Loudoun County. Total area of the Blue Ridge is $825.5 \mathrm{~km}^{2}$ or about 62 per cent of the county.

The locations of the wells in the Blue Ridge of Loudoun County are shown in figure 1. In the figure, it is obvious that the wells are not distributed evenly throughout the Blue Ridge. They form clusters in communities and subdivisions, strings of wells outline highways, and some rock units have many hundreds of wells while others have as few as one well.

Wells in Middle Proterozoic age rocks total 2,717 and make up more than 66 per cent of the wells in the data set. In this age class, the Biotitic Marshall Metagranite (Ymb) has the most wells drilled (868), about 21 percent of the total. Wells in Late Proterozoic age rocks total 1,171 and make up more than 28 per cent of the number of nonzero wells. The Late Proterozoic age rock unit having the most wells is Catoctin Formation metabasalt $(\mathrm{Zc})$ with 724 wells. There are 211 wells in Cambrian rocks or 5 per cent of the total number of zero-yield wells, with Harpers Formation phyllite $(\mathrm{Ch})$ rocks having the majority of the wells. The 16 wells in Jurassic diabase dikes (Jd) account for less than 0.4 per cent of the nonzero-yield wells.

The mean yield of the nonzero-yield wells for each rock type present in the Blue Ridge of the county are shown also in table 1. Total mean yield for all rock types is $15.52 \mathrm{gpm}$, but the mean yield of an individual rock type may vary from $30.00 \mathrm{gpm}$ for the one well drilled into Catoctin metasandstone (Zcs) and 24.82 gpm for the 57 wells drilled into Swift Run metagraywacke (Zss) to 3.50 gpm for the 6 wells drilled into Tomstown Formation dolostone (Ct). Note that the 868 wells drilled into Biotitic Marshal Metagranite $(\mathrm{Ymb})$ and the 603 wells drilled into Garnetiferous metagranite(Ygt) average 16.72 and $16.345 \mathrm{gpm}$, respectively, while the 724 wells drilled into Catoctin Formation metabasalt $\left(Z_{c}\right)$ have a much lower yield of $11.72 \mathrm{gpm}$. 


\section{Analysis of Variance}

A one-way analysis of variance was used to test the hypothesis that the mean well yields are not significantly different across rock types. This is a standard procedure to test for differences between means. It partitions the total variability of yield into variability between rock types and within rock types. This latter term is often called the error. The null hypothesis of no significant difference in the mean yields was tested for the 16 rock types in which 30 or more wells had been drilled. A minimum sample size of 30 was chosen to ensure the stability of the results. The results of the hypothesis test are shown in table 2 where it can be seen that the null hypothesis was rejected at a probability level of less that one chance in a thousand of being true. That is, there is a least one of the observed comparisons that can be made between the observed mean yields across the 16 rock types that is sufficiently large as to have occurred at random less than one time in a thousand. When the null hypothesis of equal means is true, the mean square for rock type (table 2 ) is to within sampling variability equal to the mean square error. The ratio of these two quantities, known as the F-ratio, becomes larger when the null is more likely to be false, as it is for this data set.

Inspection of the Bonferroni ${ }^{4}$ probabilities for each of the pair comparisons (table 3) shows that there are 11 such pairs of mean differences that contributed to the rejection of the null hypothesis that there is no difference among the mean yields. The most striking comparisons are between Harper's Formation phyllite (Ch) and the Middle and Late Proterozoic rocks, where we find nine possible comparisons among the mean yields to be statistically significant, that is, having a value of 0.050 or less. The second strongest and only other set of differences is between Catoctin Formation metabasalt $(\mathrm{Zc})$ rock types and the other rock types, where four significant comparisons exist (with $\mathrm{Ygt}, \mathrm{Ymc}$, and Ch).

The significance between the means is shown graphically in Figure 2, where it can be seen that the mean yield and the confidence interval for Harper's Formation phyllite $(\mathrm{Ch})$ is out of the range of the confidence limits for all but one other rock types-- the Antietam quartzite (Ca)-- as was shown by the significant

${ }^{4}$ Bonferroni is a statistical procedure designed to protect against incorrectly rejecting the null hypothesis. 
probabilities in column 2 of table 3. To a similar degree, Swift Run metagraywacke (Zss) has a mean yield that is higher than all other rock types but a mean yield that is significantly higher than only Harper's Formation phyllite (Ch). To a much lesser degree, Antietam quartzite (Ca) has a mean yield that is less than all rock types other than Harper's Formation phyllite (Ch), however, the wide range of the error bars precludes well yield from the Antietam quartzite from being significantly different than any other rock type. Coarse-grained Marshall metagranite $(\mathrm{Ymc})$ has a mean yield that is greater than most other rock types and narrow confidence limits that overlap with few of those other rock types.

\section{Variography}

In water-well variography, only data from low-yield wells (wells with yields of less than $40 \mathrm{gpm}$ ) are used, because their variogram surfaces have been shown by Drew and others (1999) in the Pinardville, NH, quadrangle to have anisotropies that imply a spatial continuity between the yield of one low-yield well to that of another. Thus we have chosen to perform the analysis using the same methods for the Blue Ridge of Loudoun County. These anisotropies are linked to the local bedrock geology. The variogram surface of the high-yield wells, those yielding $40 \mathrm{gpm}$ or higher, do not have such anisotropies, because there is no spatial continuity between the yield of one high-yield well to that of another.

The software used in variography (Variowin) has limits to the number of pairs that can be compared, so subsets of the well data were used in the variography.

Preliminary variography with the above subset confirms links between the bedrock geology and the water-well yields similar to those first described in Drew and others (1999) for the Pinardville, NH, quadrangle. Figure 3 shows the variogram surface for the 1,232 nonzero low-yield wells in rocks of the Marshall granite ( $\mathrm{Ymb}, \mathrm{Ymc}$, and $\mathrm{Yml})$. There is an anisotropy trending about N54E through the middle of the variogram, which may correspond to the general compressional trend of the Blue Ridge. The anisotropy is not clearly defined, perhaps because the surface is a composite of data from three rock types. These 
rock types, being of different textures, may have somewhat different geologic histories and fabrics that influence the connectivity of the wells. Weak patches of local lows trend at right angles to the overall trend of the anisotropy, which may be indicative of another tectonic fabric affecting well interconnectivity, such as the locally northwest-trending contacts between the Middle Proterozoic units. Further variography with other subsets, broken out by rock type and possibly adjusted for trends in yields brought about by improved drilling technology, may be able to reduce the anisotropy into its components.

\section{Conclusion}

It was been shown statistically that there are significant differences in waterwell yields across rock types in the Blue Ridge of Loudoun County, Virginia. Wells drilled in Harper's Formation phyllite, for example, have significantly lower yields than wells in any other rock type, and yields from wells in the Catoctin formation metabasalt are significantly different than yields from wells in rocks of two rock types other than Harper's Formation phyllite. The greatest range in yields is found in the Cambrian to Late Proterozoic metasedimentary and meta-igneous cover-sequence rocks of the Blue Ridge, whereas the mostly granitic Middle Proterozoic rocks exhibit a much narrower range of yields. This demonstrates that bedrock lithology does influence yield in western Loudoun County.

One composite variogram surface for the Marshall granite has shown that yields of low-yield wells have anisotropies linked to the bedrock geology of the Blue Ridge of Loudoun County. Further variography can be done to disaggregate the data by rock type or geographic area to further refine the variograms so that additional anisotropies can be recognized. Rock fracture patterns and fabrics seen in the field may contribute to these anisotropies or the anisotropies may lead to identification of additional patterns in the rocks. 


\section{References Cited}

Daniel, C.C., III, 1989, Statistical analysis relating well yield to construction practices and siting of wells in the Piedmont and Blue Ridge Provinces of North Carolina: U.S. Geological Survey Water-Supply Paper, 2341-A, 27 p.

Drew, L.J., Karlinger, M.R., Armstrong, T.R., and Moore, R.B., 1999, Relations between igneous and metamorphic rock fracture patterns and groundwater yield from the variography of water-well yields-Pinardville quadrangle, New Hampshire: Natural Resources Research, v. 8, no. 2, p. 137-152.

Southworth, Scott, Burton, W.C., Schindler, J.S., and Froelich, A.J., 1999, Digital geologic map of Loudoun County, Virginia: U.S. Geological Survey OpenFile Report, 99-150, scale 1:50,000. 
Table 1. Rock types and their nonzero-yield water wells in the Blue Ridge Province of Loudoun County, Virginia, sorted by geologic age and alphabetically. (Geologic abbreviations are from Southworth and others, 1999. Rock types are condensed from Southworth and others, 1999.)

\begin{tabular}{|c|c|c|c|c|}
\hline $\begin{array}{c}\text { Geologic } \\
\text { abbreviation }\end{array}$ & $\begin{array}{c}\text { Age } \\
\text { Rock type }\end{array}$ & $\begin{array}{r}\text { Area } \\
\left(\mathrm{km}^{2}\right)\end{array}$ & $\begin{array}{l}\text { Number } \\
\text { of wells }\end{array}$ & $\begin{array}{l}\text { Mean yield } \\
\text { (gpm) }\end{array}$ \\
\hline & $\begin{array}{l}\text { Jurassic } \\
\end{array}$ & & & \\
\hline $\mathrm{Jd}$ & $\begin{array}{r}\text { Diabase dikes and sheets } \\
\text { Cambrian }\end{array}$ & 3.0 & 16 & 12.81 \\
\hline $\mathrm{Ca}$ & Antietam quartzite & 1.6 & 31 & 15.22 \\
\hline Cсp & Carbonaceous phyllite & 0.6 & 7 & 17.61 \\
\hline $\mathrm{Ch}$ & $\begin{array}{l}\text { Harpers Formation phyllite and } \\
\text { metasiltstone. }\end{array}$ & 15.7 & 120 & 7.80 \\
\hline $\mathrm{Cl}$ & Loudoun, phyllite & 3.0 & 1 & 4.00 \\
\hline $\mathrm{Ct}$ & Tomstown Dolomite & 0.6 & 6 & 3.50 \\
\hline $\mathrm{Cw}$ & Weverton Formation quartzite & 5.8 & 23 & 7.43 \\
\hline Cwl & Weverton Formation, lower member & 10.6 & 11 & 17.68 \\
\hline Cwm & $\begin{array}{l}\text { Weverton Formation middle member, } \\
\text { quartzite }\end{array}$ & 10.9 & 11 & 26.09 \\
\hline Cwu & $\begin{array}{l}\text { Weverton Formation upper member } \\
\text { quartzite and quartz pebble conglomerate } \\
\text { Late Proterozoic }\end{array}$ & 3.0 & 1 & 12.00 \\
\hline Zc & Catoctin Formation metabasalt & 191.0 & 724 & 11.72 \\
\hline $\mathrm{Zcm}$ & Catoctin Formation marble & 2.2 & 4 & 21.38 \\
\hline Zcp & $\begin{array}{l}\text { Catoctin Formation quartz muscovite } \\
\text { phyllite }\end{array}$ & 7.5 & 13 & 23.46 \\
\hline Zcr & Catoctin Formation metatuff & 0.9 & 11 & 10.54 \\
\hline Zcs & Catoctin Formation metasandstone & 0.3 & 1 & 30.00 \\
\hline Zfa & Fauquier Formation meta-arkose & 6.4 & 17 & 14.98 \\
\hline $\mathrm{Zfs}$ & Fauquier Formation metamudstone & 2.1 & 7 & 20.29 \\
\hline Zmd & Metadiabase dikes & 50.1 & 259 & 16.96 \\
\hline Zrd & Metarhyolite dikes & 1.2 & 7 & 7.57 \\
\hline Zrr & $\begin{array}{l}\text { Granite of the Robertson River Intrusive } \\
\text { Suite }\end{array}$ & 3.5 & 2 & 18.50 \\
\hline Zsm & Swift Run Formation marble & 0.2 & 1 & 8.00 \\
\hline Zsp & $\begin{array}{l}\text { Swift Run Formation marble, slate, and } \\
\text { phyllite }\end{array}$ & 9.1 & 68 & 19.47 \\
\hline Zss & $\begin{array}{c}\text { Swift Run Formation metagraywacke } \\
\text { Middle Proterozoic }\end{array}$ & 8.4 & 57 & 24.82 \\
\hline Ybg & Biotite granite gneiss & 12.1 & 74 & 16.09 \\
\hline$Y_{c}{ }^{\circ}$ & Charnockite & 4.6 & 16 & 11.17 \\
\hline $\mathrm{Yg}$ & Leucocratic metagranite & 38.7 & 265 & 12.76 \\
\hline Ygt & Garnetiferous metagranite & 104.4 & 603 & 16.34 \\
\hline Yhm & Hornblende monzogranite gneiss & 43.7 & 210 & 14.73 \\
\hline Ylg & Layered granite gneiss & 49.8 & 160 & 15.98 \\
\hline $\mathrm{Ymb}$ & Marshall metagranite, biotitic & 146.1 & 868 & 16.72 \\
\hline Ymc & Marshall metagranite, coarse grained & 20.7 & 197 & 22.74 \\
\hline Yml & Pink leucocratic metagranite & 27.5 & 167 & 21.10 \\
\hline Yn & Metanorite & 6.3 & 29 & 10.92 \\
\hline $\mathrm{Yp}$ & Paragneiss & 6.9 & 49 & 12.66 \\
\hline Ypg & Porphyroblastic granite gneiss & 27.0 & 79 & 13.88 \\
\hline Totals & & 825.5 & 4,115 & 15.52 \\
\hline
\end{tabular}


Table 2. Analysis of variance

\begin{tabular}{cccccc}
\hline \multicolumn{7}{c}{ Analysis of variance } \\
\hline Source & Sum-of-squares & $\mathrm{df}$ & Mean-square & F-ratio & $\mathrm{P}$ \\
\hline Rock type & 39.209 & 15 & 2.614 & 6.050 & 0.000 \\
Error & 1691.494 & 3915 & 0.432 & n.a. & n.a. \\
\hline
\end{tabular}


Table 3. Bonferroni adjustment for significance level between pairs of yields with rock types. Pairs havin the 0.050 level or less are in bold. Geologic abbreviations are found in table 1 and in Southworth and oth

\begin{tabular}{|c|c|c|c|c|c|c|c|c|c|c|c|c|c|}
\hline & \multicolumn{13}{|c|}{ Rock type } \\
\hline & $\mathrm{Ca}$ & $\mathrm{Ch}$ & Ybg & $\mathrm{Yg}$ & Ygt & Yhm & Ylg & Ymb & Ymc & Yml & $Y p$ & Ypg & $\mathrm{Zc}$ \\
\hline $\mathrm{Ca}$ & 1.000 & & & & & & & & & & & & \\
\hline $\mathrm{Ch}$ & 1.000 & 1.000 & & & & & & & & & & & \\
\hline Ybg & 1.000 & 1.000 & 1.000 & & & & & & & & & & \\
\hline $\mathrm{Yg}$ & 1.000 & 0.000 & 1.000 & 1.000 & & & & & & & & & \\
\hline Ygt & 1.000 & 0.000 & 0.564 & 1.000 & 1.000 & & & & & & & & \\
\hline Yhm & 1.000 & 0.000 & 1.000 & 1.000 & 1.000 & 1.000 & & & & & & & \\
\hline Ylg & 1.000 & 0.000 & 1.000 & 1.000 & 1.000 & 1.000 & 1.000 & & & & & & \\
\hline Ymb & 1.000 & 0.000 & 1.000 & 1.000 & 1.000 & 1.000 & 1.000 & 1.000 & & & & & \\
\hline Ymc & 1.000 & 0.000 & 0.054 & 0.651 & 1.000 & 1.000 & 1.000 & 0.180 & 1.000 & & & & \\
\hline Yml & 1.000 & 0.000 & 1.000 & 1.000 & 1.000 & 1.000 & 1.000 & 1.000 & 1.000 & 1.000 & & & \\
\hline$Y p$ & 1.000 & 0.619 & 1.000 & 1.000 & 1.000 & 1.000 & 1.000 & 1.000 & 1.000 & 1.000 & 1.000 & & \\
\hline Ypg & 1.000 & 0.391 & 1.000 & 1.000 & 1.000 & 1.000 & 1.000 & 1.000 & 0.899 & 1.000 & 1.000 & 1.000 & \\
\hline $\mathrm{Zc}$ & 1.000 & 0.002 & 1.000 & 1.000 & 0.004 & 1.000 & 1.000 & 1.000 & 0.001 & 0.777 & 1.000 & 1.000 & $1 .($ \\
\hline $\mathrm{Zmd}$ & 1.000 & 0.003 & 1.000 & 1.000 & 1.000 & 1.000 & 1.000 & 1.000 & 0.088 & 1.000 & 1.000 & 1.000 & $1 .($ \\
\hline Zsp & 0.991 & 0.000 & 0.151 & 1.000 & 1.000 & 1.000 & 1.000 & 1.000 & 1.000 & 1.000 & 1.000 & 1.000 & 0.1 \\
\hline Zss & 0.782 & 0.000 & 0.129 & 1.000 & 1.000 & 1.000 & 1.000 & 1.000 & 1.000 & 1.000 & 1.000 & 1.000 & 0.1 \\
\hline
\end{tabular}




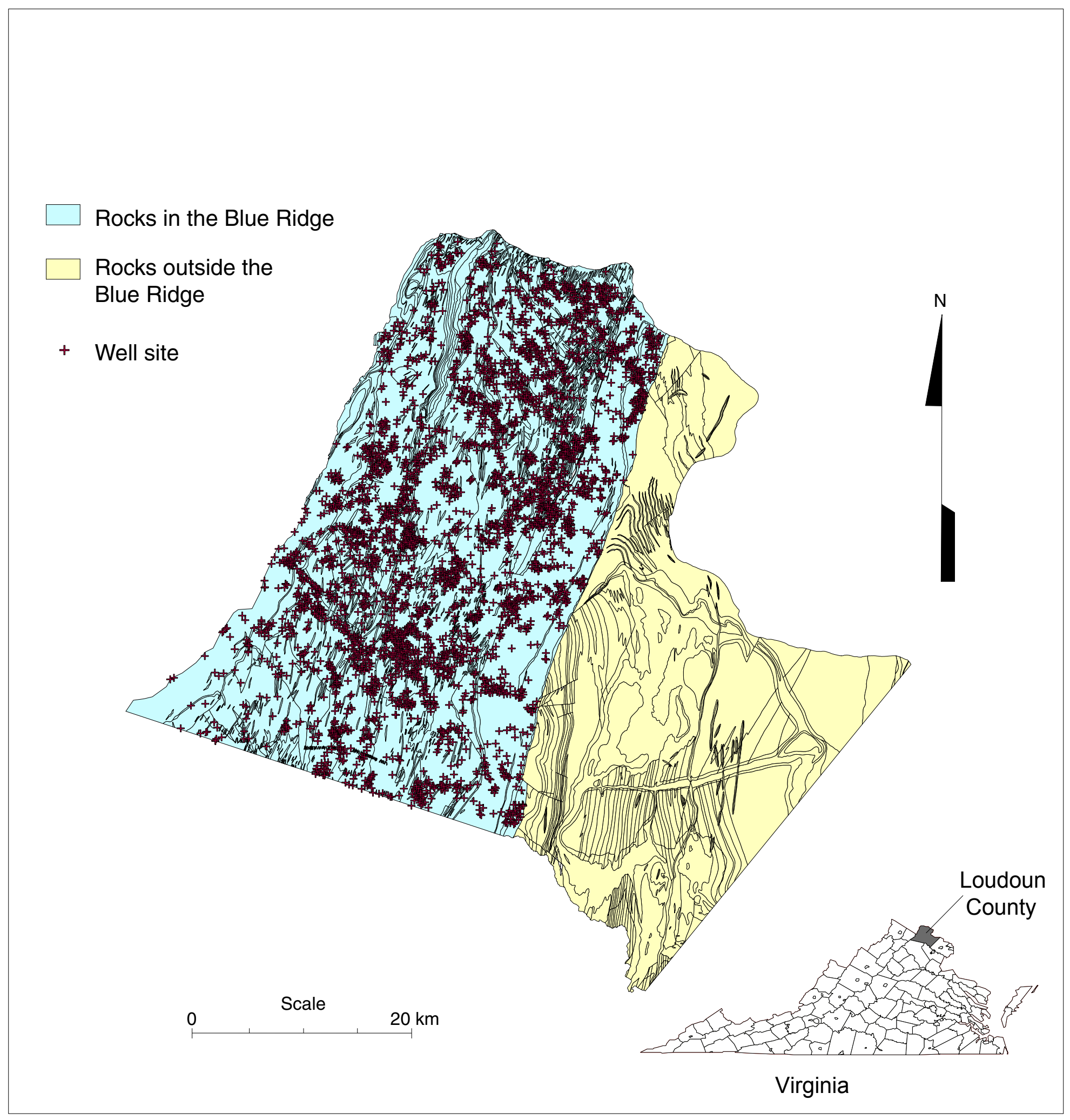

Figure 1. Locations of water wells in the Blue Ridge of Loudoun County, Virginia. Geology after Southworth and others (1999). 


\section{Least Squares Means}

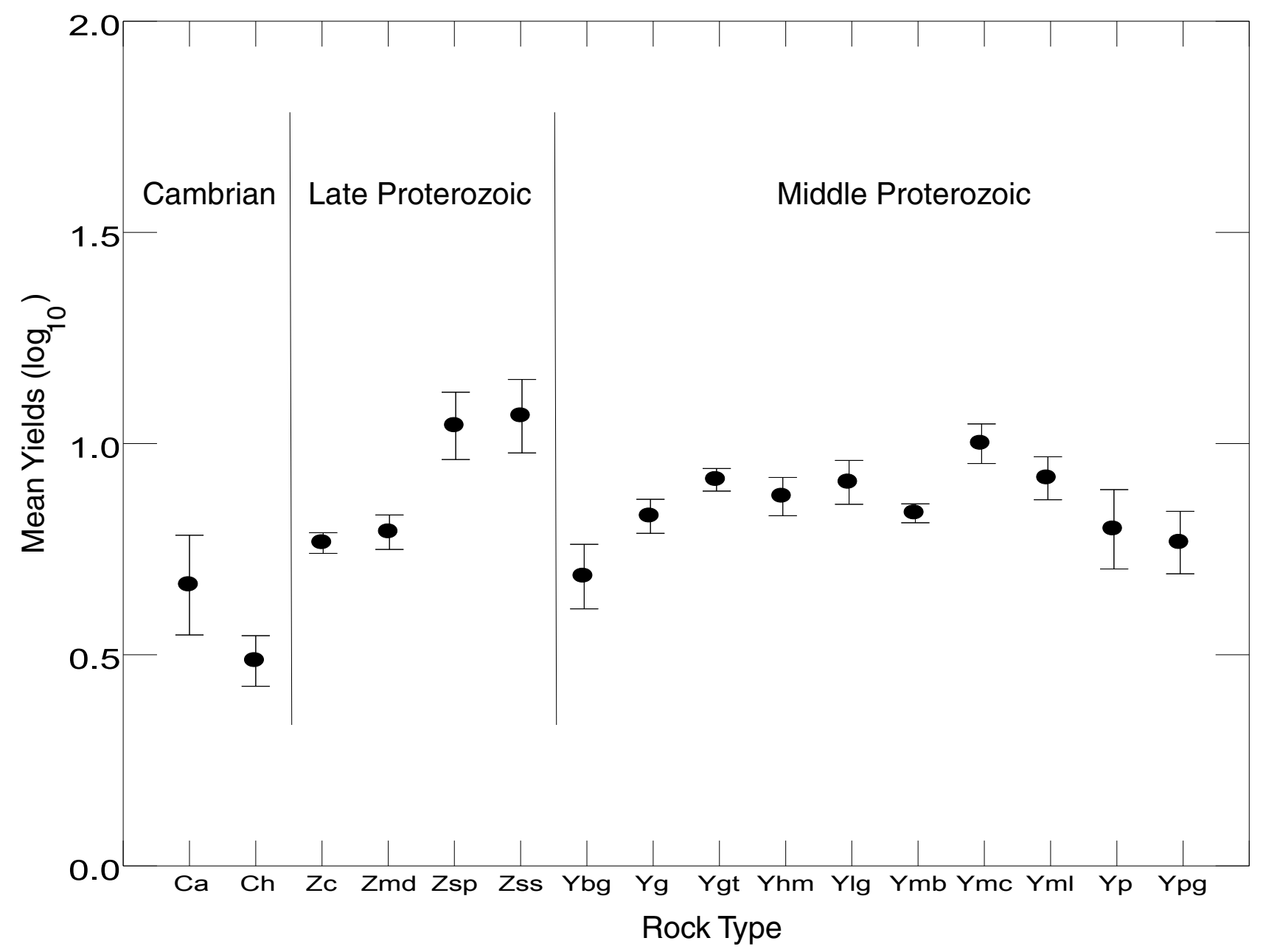

Figure 2. Mean $\log _{10}$ yields of wells in rock types in the Blue Ridge of Loudoun County, Virginia, having 30 or more wells. Rock types are defined in table 1 and are listed alphabetically within ages. 


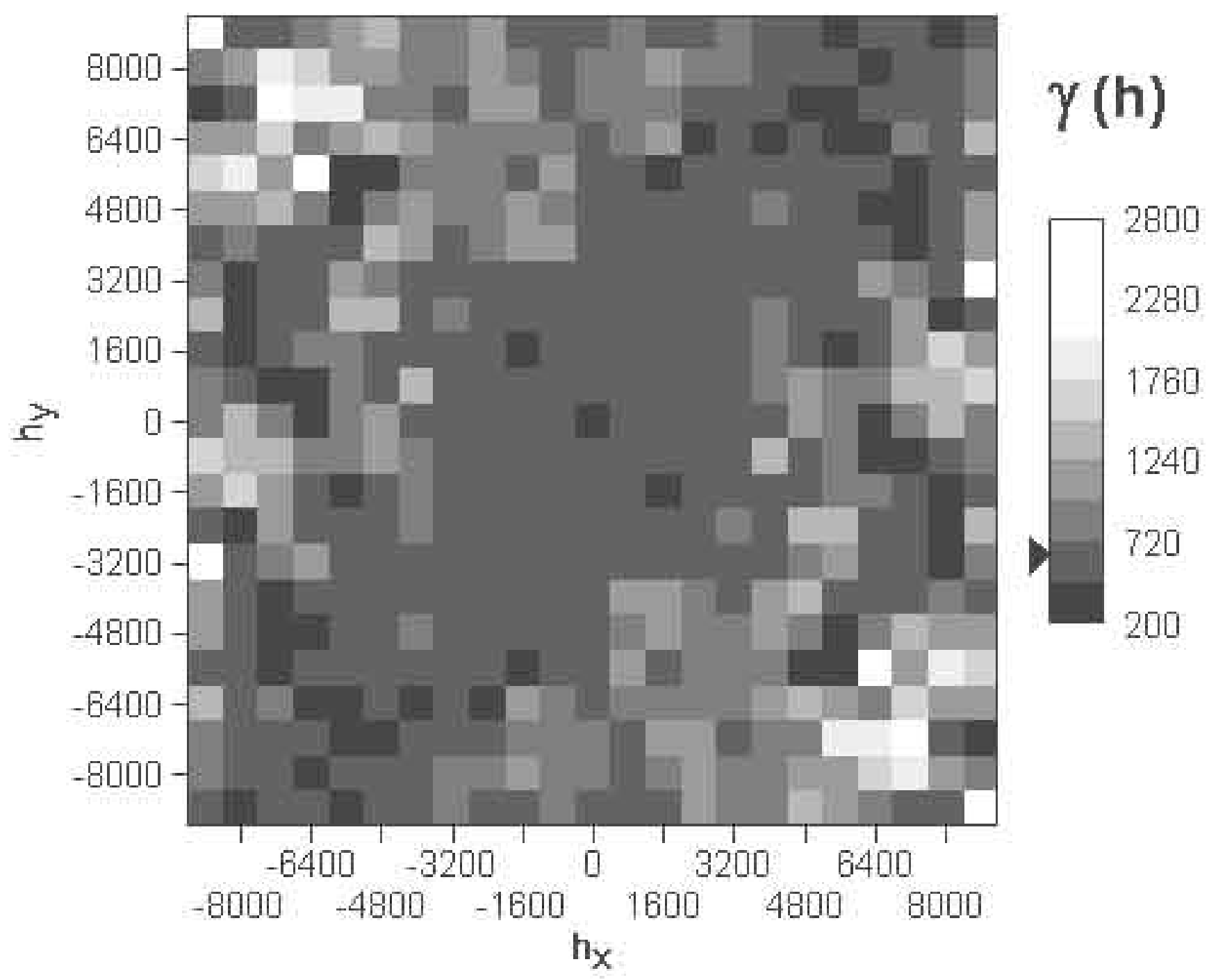

Figure 3. Variogram surface for 1,232 low-yield wells of the Marshall metagranite (Ymb, Ymc, and $\mathrm{Yml}$ ) in the Blue Ridge of Loudoun County, Virginia. Lag spacing is $800 \mathrm{~m}$ with 11 lags. 